\title{
Contrivance of 5s System to Effectuate Higher Productivity in Apparel Industries
}

\author{
By Jaglul Hoque Mridha, A.M. Riasat Alam, Tanvir Mahmud \\ \& Tanvir Ahmed \\ Northern University Bangladesh
}

Abstract- Bangladesh is the second largest exporter of readymade garment (RMG) products in the world after China. Above $80 \%$ of its total export earning is contributed by the RMG sector which has a huge impact on the economy of the country. At present this RMG sector is facing many threats and challenges to hold its flourishing position because of the entrance of new competitors both in the national and international market. To overcome these challenges continuous improvement is required to a great extent. This paper experiments execution of $5 S$ approach to a production scenario in a garments industry. 5S method should be improved to ensure ergonomics in the workplace, to reduce defects and increase cleaning and productivity growth. It is one of the fundamental tools to intensify continuous improvement process in organizations and represents a transformation in 5 steps of a job, which is characterized by maximum efficiency at the micro level and minimum loss. Any company applying the $5 \mathrm{~S}$ methodology will have reduction of different types of waste, efficient workflow due to lesser machine breakdowns, lower defect rates, reduced inventory and effective problem visualization, visible and swift results in an efficient way.

Keywords: productivity growth, apparel industry, inventory, visual control management.

GJRE-J Classification: FOR Code: 091012

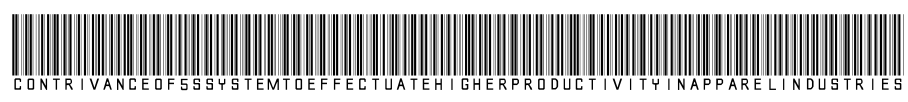

Strictly as per the compliance and regulations of:

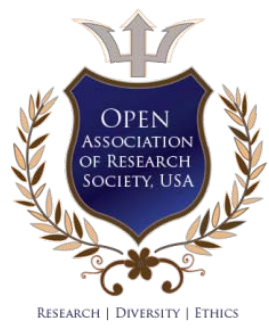

(C) 2020. Jaglul Hoque Mridha, A.M. Riasat Alam, Tanvir Mahmud \& Tanvir Ahmed. This is a research/review paper, distributed under the terms of the Creative Commons Attribution-Noncommercial 3.0 Unported License http://creativecommons.org/licenses/by-nc/3.0/), permitting all non commercial use, distribution, and reproduction in any medium, provided the original work is properly cited. 


\title{
Contrivance of 5s System to Effectuate Higher Productivity in Apparel Industries
}

\author{
Jaglul Hoque Mridha ${ }^{\alpha}$, A.M. Riasat Alam ${ }^{\sigma}$, Tanvir Mahmud ${ }^{\rho} \&$ Tanvir Ahmed $^{\omega}$
}

Abstract- Bangladesh is the second largest exporter of readymade garment (RMG) products in the world after China. Above $80 \%$ of its total export earning is contributed by the RMG sector which has a huge impact on the economy of the country. At present this RMG sector is facing many threats and challenges to hold its flourishing position because of the entrance of new competitors both in the national and international market. To overcome these challenges continuous improvement is required to a great extent. This paper experiments execution of $5 \mathrm{~S}$ approach to a production scenario in a garments industry. 5S method should be improved to ensure ergonomics in the workplace, to reduce defects and increase cleaning and productivity growth. It is one of the fundamental tools to intensify continuous improvement process in organizations and represents a transformation in 5 steps of a job, which is characterized by maximum efficiency at the micro level and minimum loss. Any company applying the $5 \mathrm{~S}$ methodology will have reduction of different types of waste, efficient workflow due to lesser machine breakdowns, lower defect rates, reduced inventory and effective problem visualization, visible and swift results in an efficient way.

Keywords: productivity growth, apparel industry, inventory, visual control management.

\section{INTRODUCTION}

T he apparel industries in Bangladesh are mainly export-oriented. Knit and woven garments are the main products. During the past two decades, the success of readymade garment exports from Bangladesh has exceeded the most optimistic standards. In terms of country employment, foreign exchange earnings and its contribution to real GDP, this $\mathrm{RMG}$ sector has rapidly gained immense importance. To sustain this rapid growth and satisfy customer demand, the companies need to create some new work practices instead of traditional practices. Applying LEAN techniques like the 5 S system can result in improved productivity, cost savings, and workflow efficiency.

a) Objectives:

- To identify the $5 \mathrm{~S}$ principles in Apparel Industry to find out the desired Productivity \& Improve efficiency in Production line of apparel Industry.

Author a $\sigma$ p: Lecturer, Department of Textile Engineering, Northern University Bangladesh. e-mails: jaglul.mridha92@gmail.com, riasat.alam@gmail.com, tanvirmahmud002@gmail.com

Author w: Merchandiser, Hameem Group, Bangladesh.

e-mail: tanvir.butex.tem.38@gmail.com
- To identify the factors influencing in Productivity in Apparel Industry.

- To analyze the effect of 5S Principles on Apparel Productivity.

- To contemplate the pursuance in terms of manufacturing and environmental key performance indicators namely productivity, efficiency, quality, work in progress among 5S initiated and non- 5S initiated apparel units.

- Elimination of waste like and create an action plan for continuous improvement.

\section{il. Literature Review}

$5 S$ is a simple tool of the LEAN management for organizing your workplace in a clean, efficient and safe manner to enhance productivity, visual management and to ensure the introduction of standardized working of an organization.

The 5 phases are:

- Sort (Seiri)- "When in doubt, throw it out".

- Straighten (Seiton) -"A place for everything, and everything in its place".

- Shine (Seiso) - "The best cleaning is to not need cleaning".

- Standardize (Seiketsu) - "See and recognize what needs to be done".

- Sustain (Shitsuke) - "The less self-discipline you need, the better".

The system creates an environment where all objects are easier to find and any deviation from the normal situation becomes apparent by visual management methods. In the same time, 5 S techniques maintain quality, promote a significant costs reduction by eliminating the losses and provides the best framework for progress throughout the organization.

These five phases of $5 S$ system has a great impact in reducing the seven deadly wastes or MUDAS of an organization. These seven deadly wastes are:

1. Defect

2. Inventory

3. Processing

4. Waiting

5. Motion

6. Transportation

7. Overproduction 


\section{ili. Methodology}

This section describes different areas related to the study and also the tools and techniques used in this study. It is a basic technique to enhance workplace appearance and give a pleasant work environment.

During our research on the project, we have visited some renowned garments manufacturing companies named Epyllion Styles Ltd. There we have met with the authority to perform our research on the 5S system. There we follow some of the steps to implement the research work:

$>$ Discussed with the top management about the ways they follow to implement 5S system in their apparel industry.

$>$ Used survey method and questionnaire method to collect necessary data and information from the IE department for the research work.

$>$ Made effective analysis and survey of each department to gather some valuable data and photos which is needed for the project research work.

> Made some search from these company's web sites to collect necessary information, comparable data etc.

$>$ All the necessary task were done for the project work during the time period from June to August, 2016.

\section{a) Data collection and analysis}

The five concepts, which have to be checked, introduced and implemented in the workplace by the garments industries, where we have made our research are: i. Seiri (Sort)

- Take some photos which are needed to analyze the study.

- Segregate wanted \& unwanted materials in all Zones.

ii. Seiton (Set in Order)

- Identify all materials by Name/Number/Colour code, etc.

- Design a suitable storage place/parking slots and fix the place for storing each item depending on the frequency of usage

iii. Seiso (Shine)

- Prepare cleaning schedule for all zones covering.

- The areas of cleaning

- The items of cleaning

iv. Seiketsu (Standardise)

- Make a list of the various activities of 5S for implementation.

- Follow the significant guidelines for floor marking in the industry.

- The following things to be standardized.

v. Shitsuke (Sustain)

- Monitor all the activities of $5 S$ continuously.

- Create work discipline with the help of employees working in the particular area in order to suit the requirement

b) Case study

We have found some problems in different sections of the garments industry and found some actions required to solve the issues which are given below in the table:

\begin{tabular}{|c|c|c|c|c|c|c|c|c|}
\hline Problems & $\begin{array}{c}\text { Sample } \\
\text { Dept. }\end{array}$ & Stores & Cutting & Stitching & Finishing & Packing & $\begin{array}{c}\text { Office } \\
\text { Area }\end{array}$ & $\begin{array}{c}\text { Action } \\
\text { Required }\end{array}$ \\
\hline Unnecessary Items & Yes & Yes & No & Yes & Yes & Yes & Yes & Seiri \\
\hline Leftover Present & Yes & Yes & Yes & Yes & Yes & Yes & No & Seiri \\
\hline Rejection On Floor & No & Yes & Yes & Yes & No & Yes & No & Seiri \\
\hline Floor Marking & Partial & No & Partial & Partial & No & No & No & Seiton \\
\hline Labels & No & No & No & No & No & No & No & Seiton \\
\hline Trolleys & Partial & Yes & No & Partial & No & No & No & Seiton \\
\hline Sub Store & No & No & No & No & No & No & No & Seiton \\
\hline Visual Controls & No & No & No & No & No & No & No & Seiton \\
\hline Pathways Defined & No & No & No & No & No & No & No & Seiketsu \\
\hline Racks And Bins & Yes & Yes & No & No & No & Yes & Yes & Seiton \\
\hline Dust And Stains & Yes & Yes & Yes & Yes & Yes & Yes & Yes & Seiso \\
\hline $\begin{array}{c}\text { Visible Sops } \\
\text { No }\end{array}$ & No & No & No & No & No & No & Seiketsu \\
\hline $\begin{array}{c}\text { Workers Training } \\
\text { Over 5s }\end{array}$ & No & No & No & No & No & No & No & Shitsuke \\
\hline Files Arrangement & No & No & No & No & No & No & No & Seiton \\
\hline
\end{tabular}


We divided the whole space available into six zones and then we identified the unwanted materials in those zones using red tags. After removing those unwanted items from the zones, can save $51.21 \mathrm{~m}^{2}$ space. Table 1 Shown the improvement in saving space on the factory floor.

Table 1: Zone wise saving space

\begin{tabular}{|c|c|}
\hline Zone & Space saving $\left(\mathrm{m}^{2}\right)$ \\
\hline Zone 1 & 0.06 \\
\hline Zone 2 & 3.1 \\
\hline Zone 3 & 2.83 \\
\hline Zone 4 & 0.69 \\
\hline Zone 5 & 21.39 \\
\hline Zone 6 & 23.14 \\
\hline Total saving space & $51.21 \mathrm{~m}^{2}$ \\
\hline
\end{tabular}

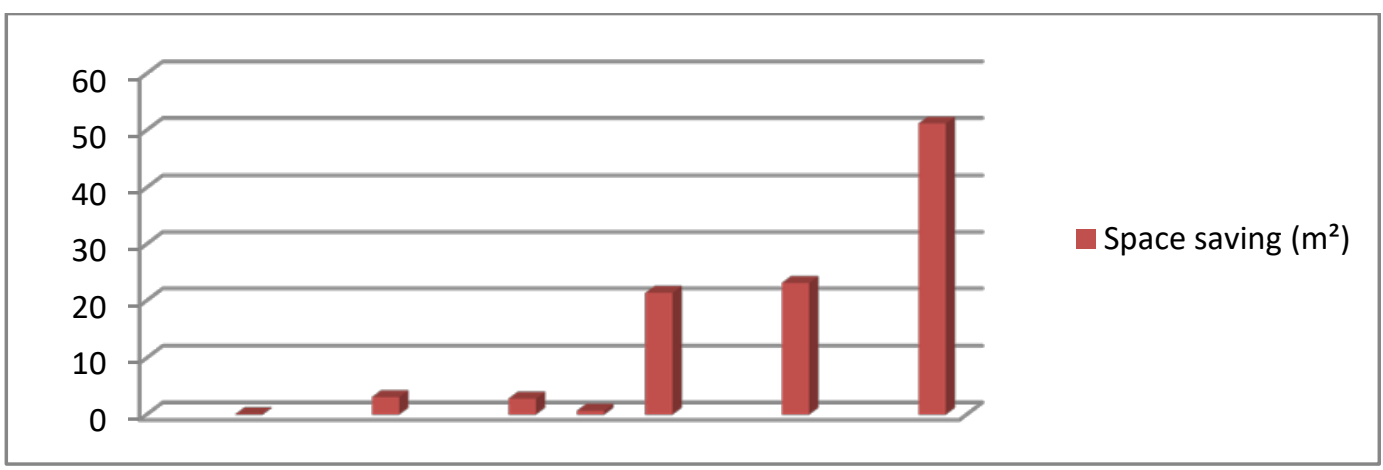

Figure 1: Different zone wise saving of apace in square meter

In zone 1 , save no space due to the removal of small quantities of items from that zone which occupied a little space. Allocate all store rooms to zone 5 and zone 6 . Found the most unwanted items in those store rooms. A comparatively a massive amount of space had been saved from zone 5 and zone 6 . This saving space resulted in an additional cost savings of 4764.09US dollars or 376363.11 Taka, which is shown in a table.

Table 2: Zone wise saving cost

\begin{tabular}{|c|c|c|}
\hline Zone & Total cost (USD) & Total cost (BDT) \\
\hline Zone 1 & 12.58 & 993.82 \\
\hline Zone 2 & 162.08 & 1204.32 \\
\hline Zone 3 & 123.67 & 9769.93 \\
\hline Zone 4 & 21.32 & 1684.28 \\
\hline Zone 5 & 3455.91 & 273016.89 \\
\hline Zone 6 & 988.53 & 78093.87 \\
\hline Total saving cost & 4764.09 & 376363.11 \\
\hline
\end{tabular}




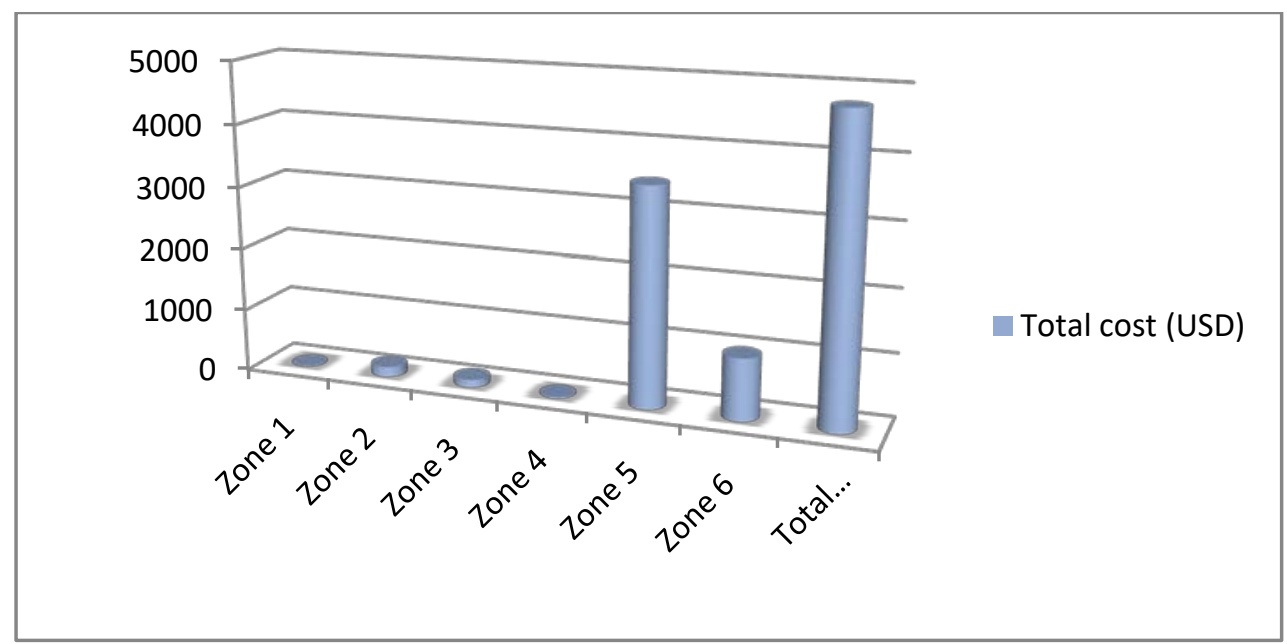

Figure 2: Zone wise total cost (USD)

Set in order was also applied in the fabric store. Before the implementation of $5 \mathrm{~s}$, there was no sequence of arranging the racks for storing fabrics. But during the study period, racks were rearranged according to the order volume of the buyer. Fabrics of higher quantity ordered were placed in initial racks while fabrics of lower quantity ordered were placed in last racks so that fabrics could be delivered with least delivery time. Rack allocation was subjected to change each month with change of buyer and order quantity. This resulted in a reduced movement of 22.95\%. Table 3 gives a clear representation of this scenario.

Table 3: Rack allocation for buyers (Before and after set in order)

\begin{tabular}{|cccc|}
\hline Buyer Order & Quantity(piece) & Rack (before) & Rack(after) \\
\hline M\&S & 15630 & 1,2 & 12 \\
\hline H\&M & 35500 & 3 & 4,510 \\
\hline C\&A & 60000 & $4,5,6$ & $1,2,3$ \\
\hline Celio & 12000 & 7 & 11 \\
\hline RAW & 25000 & 8 & 9 \\
\hline S.Oliver & 30000 & 10 & 8 \\
\hline River Islands & 15000 & 9,12 & 6,7 \\
\hline
\end{tabular}

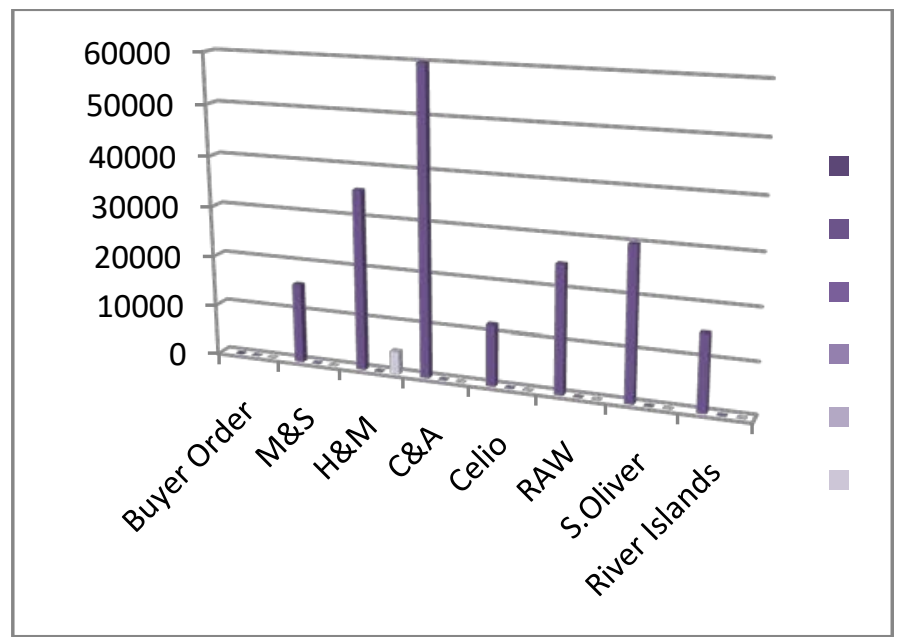

Figure 3: Different buyers and their order quantity

The same experiment done in the accessories store; a new layout was proposed and implemented based on the average quantity required/day. This experiment also resulted a reduction in overall movement of $27.13 \%$. The previous and new allocation of the accessories in the store is shown in table 4. 
Table 4: Rack allocation for accessories (Before and after set in order)

\begin{tabular}{|c|c|c|c|}
\hline Items & $\begin{array}{c}\text { Average quantity } \\
\text { required/day (bag) }\end{array}$ & Rack(before) & Rack(after) \\
\hline Thread & 3340 & $1,2,3$ & 10,11 \\
\hline Wash elastic & 70 & $4,5,6,7$ & $1,2,3$ \\
\hline Elastic tape & 90 & 8,9 & $4,5,6$ \\
\hline Button & 800 & 10,11 & 7,8 \\
\hline Zipper & 426 & 12 & $9,10,11$ \\
\hline Organic fabric & 215 & 13,14 & $12,13,14$ \\
\hline
\end{tabular}

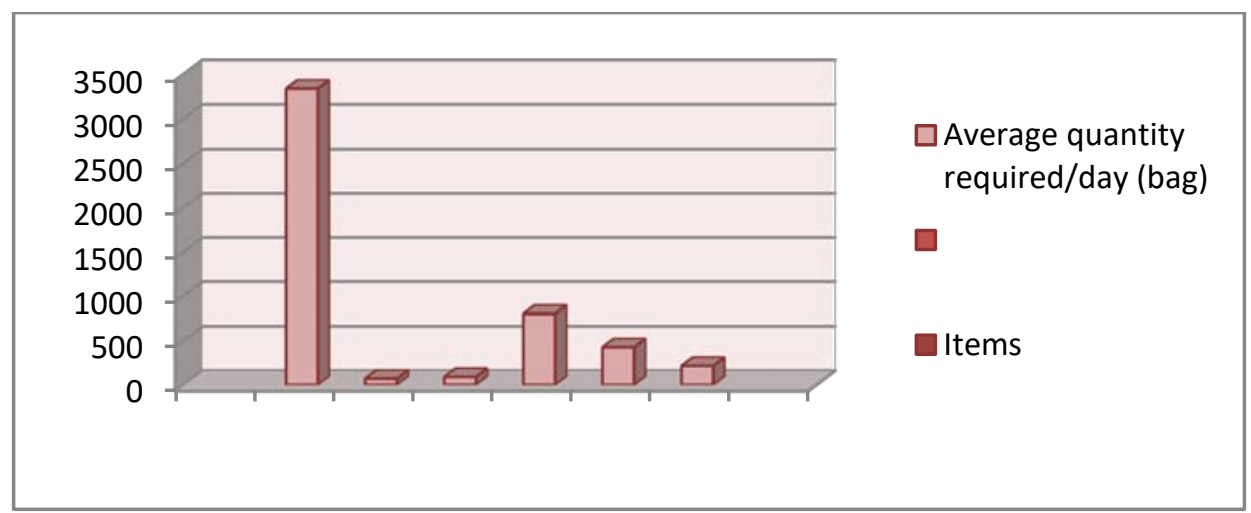

Figure 4: Rack allocation for various accessories

\section{c) Time Consuming Analysis}

Time utilization took each time the personnel or staff needed the tools or any item from the inventory places. To know how long it carry looking for the different sizes of tools before running 5S, Table 1 used to collect time in looking for a different amounts of threads. Table 2 is the data collection chart used for looking for sewing section. This data collected by the average number of 2 cycles.

Table 5: Time consumption in looking for threads of different sewing machine before 5S

\begin{tabular}{|c|c|c|c|c|c|c|}
\hline $\begin{array}{c}\text { Thread of various } \\
\text { machines }\end{array}$ & $\mathrm{M} / \mathrm{C}$ 1 (sec) & $\mathrm{M} / \mathrm{C}$ 2 (sec) & $\mathrm{M} / \mathrm{C}$ 3 (sec) & $\mathrm{M} / \mathrm{C} 4(\mathrm{sec})$ & $\mathrm{M} / \mathrm{C}$ 5 (sec) & $\mathrm{M} / \mathrm{C} 6$ (sec) \\
\hline Staff 1 & $50 \mathrm{sec}$ & 110 & 50 & 74 & 65 & 50 \\
\hline Staff 2 & $45 \mathrm{sec}$ & 115 & 65 & 70 & 69 & 35 \\
\hline Staff 3 & $40 \mathrm{sec}$ & 110 & 60 & 85 & 61 & 51 \\
\hline Staff 4 & $50 \mathrm{sec}$ & 125 & 55 & 65 & 60 & 50 \\
\hline Staff 5 & $35 \mathrm{sec}$ & 111 & 70 & 60 & 62 & 55 \\
\hline Staff 6 & $44 \mathrm{sec}$ & 115 & 75 & 75 & 75 & 30 \\
\hline Staff 7 & $40 \mathrm{sec}$ & 130 & 65 & 70 & 67 & 45 \\
\hline Staff 8 & $42 \mathrm{sec}$ & 125 & 62 & 65 & 60 & 40 \\
\hline Total(average) & 43 & 117 & 62 & 70 & 64 & 119 \\
\hline
\end{tabular}




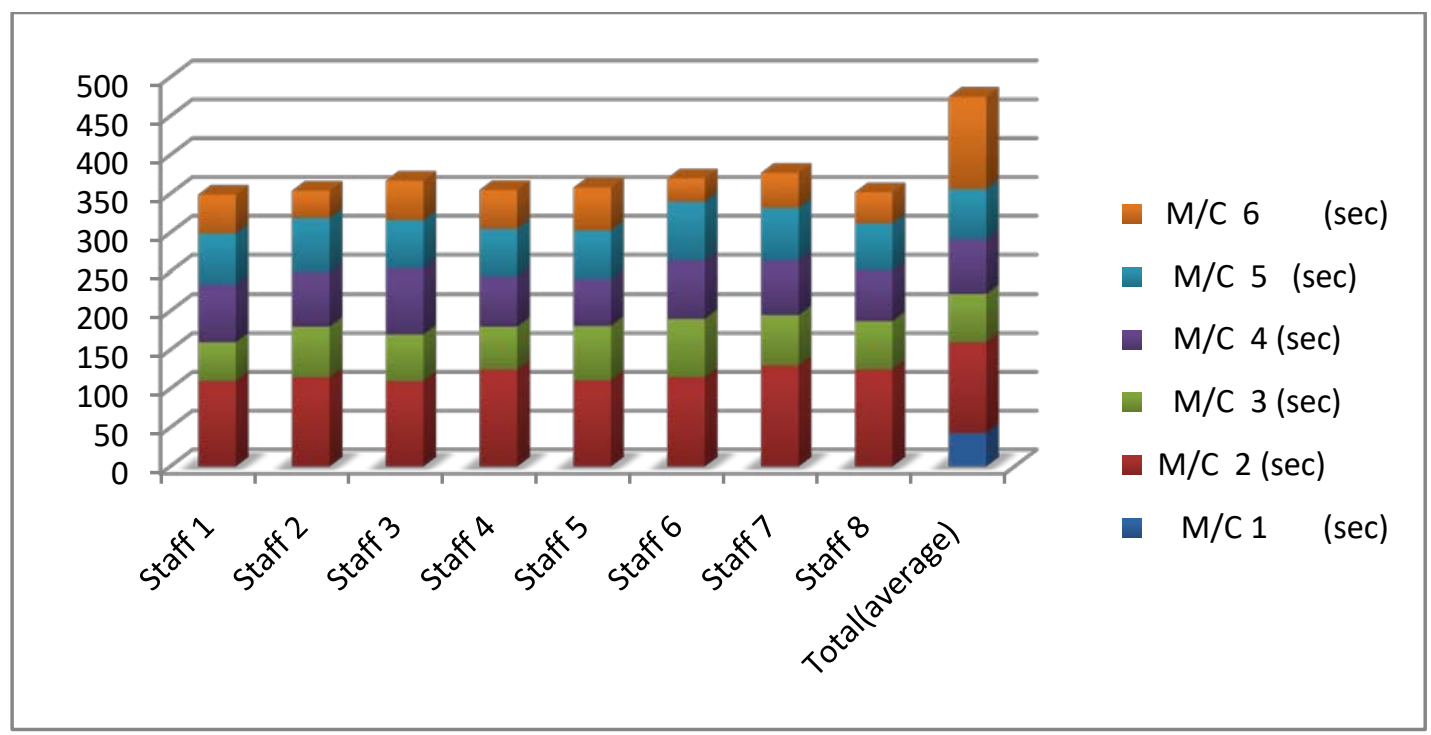

Figure 5: Time consumption to collect threads of different items of different sewing machines before implementing $5 S$

Table 6: Time consumption in looking for threads of different sewing machine after $5 \mathrm{~S}$

\begin{tabular}{|c|c|c|c|c|c|c|}
\hline $\begin{array}{c}\text { Thread of various } \\
\text { machines }\end{array}$ & M/C 1 (sec) & $M / C$ 2 (sec) & $M / C ~ 3(s e c)$ & $M / C ~ 4(s e c)$ & $M / C$ 5 (sec) & $M / C$ 6 (sec) \\
\hline Staff 1 & $15 \mathrm{sec}$ & 30 & 15 & 33 & 25 & 20 \\
\hline Staff 2 & $13 \mathrm{sec}$ & 35 & 12 & 30 & 23 & 18 \\
\hline Staff 3 & $12 \mathrm{sec}$ & 25 & 25 & 28 & 28 & 22 \\
\hline Staff 4 & $18 \mathrm{sec}$ & 40 & 23 & 42 & 33 & 21 \\
\hline Staff 5 & $15 \mathrm{sec}$ & 25 & 22 & 30 & 33 & 29 \\
\hline Staff 6 & $18 \mathrm{sec}$ & 28 & 27 & 32 & 35 & 29 \\
\hline Staff 7 & $15 \mathrm{sec}$ & 42 & 28 & 38 & 25 & 21 \\
\hline Staff 8 & $12 \mathrm{sec}$ & 25 & 30 & 35 & 39 & 15 \\
\hline Total(average) & 14 & 31 & 22 & 33 & 30 & 21 \\
\hline
\end{tabular}

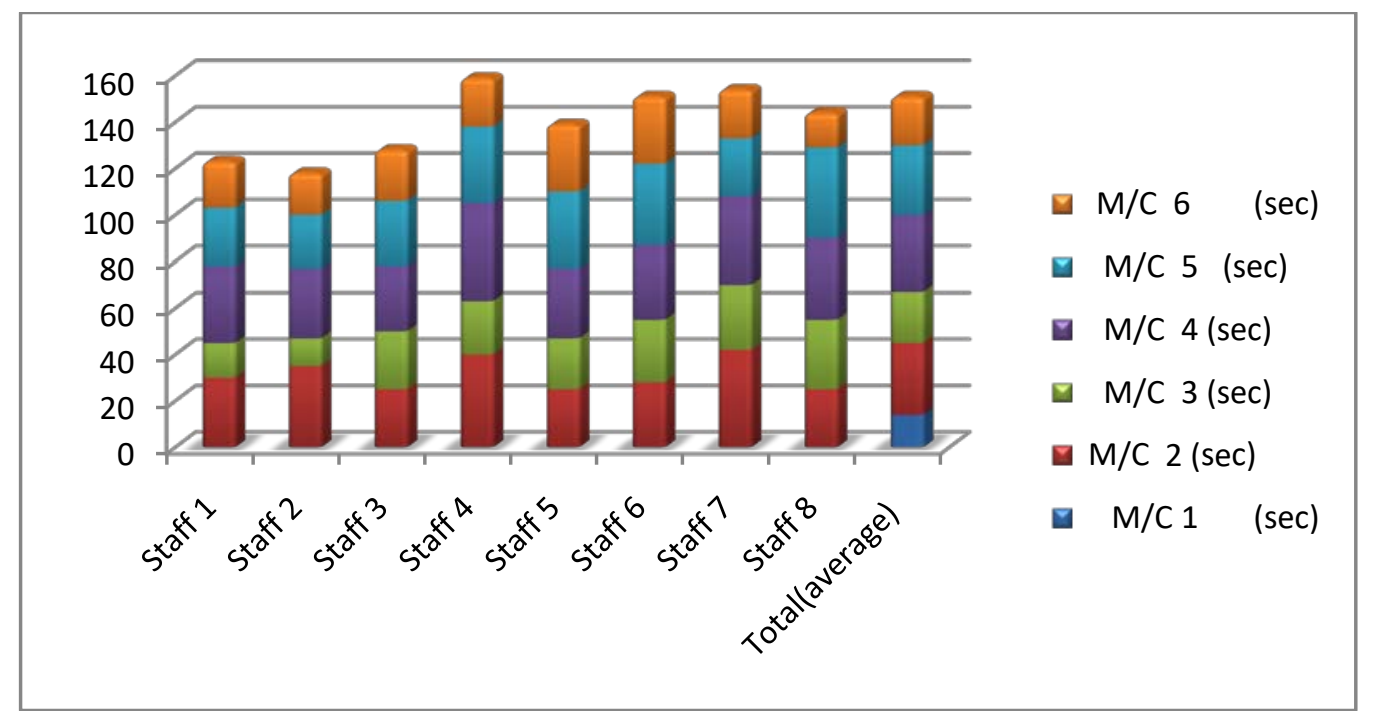

Figure 6: Time consumption to collect threads of different items of various sewing machines after implementing $5 \mathrm{~S}$ 


\section{Results and Discussions}

After the implementation of $5 \mathrm{~S}$, from the proposed improvement proposal, 51.21-meter square space was saved, which resulted in a cost savings of 376363.11 Taka. Overall reduced movement of almost $25 \%$ was achieved in the fabrics and accessories room resulting in more than a $13 \%$ increase in multifactor productivity.
After the implementation of 5S on the factory floor, it resulted in average labor productivity from 3.46 to 7.66 . This experiment showed an overall improvement of $45.17 \%$. Labor productivity calculated for one month period before, and after the implementation of 5S and the result shown in the following figure:

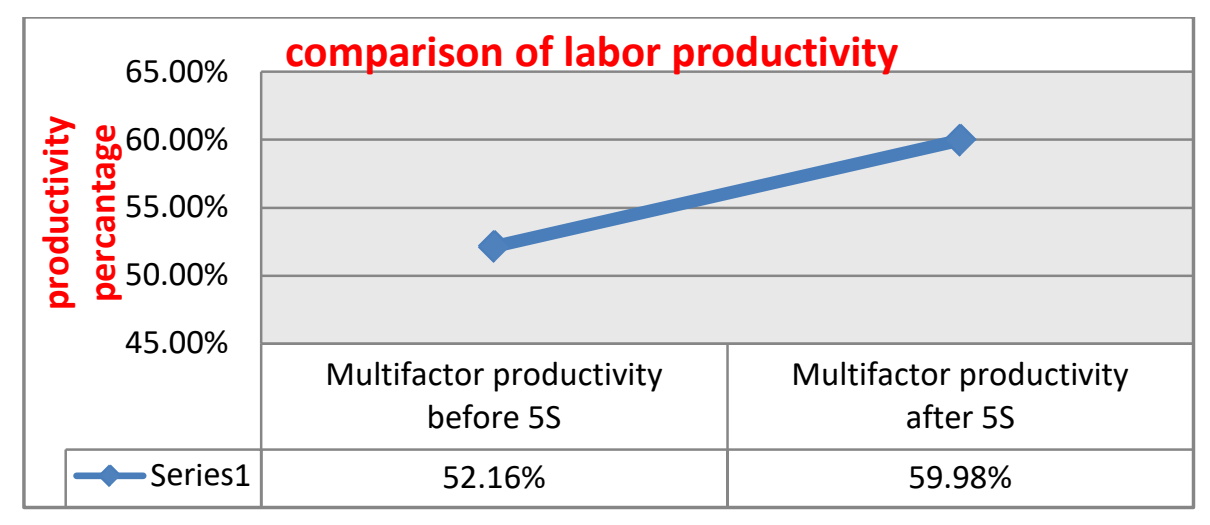

Figure 7: Comparison of labor productivity

Material productivity remained almost constant over the study period though it slightly peaked after the implementation of 5S. Average material productivity increased from 2.69 to 2.92 over the study period and resulting in a more than $15 \%$ increase in multifactor productivity. Before the implementation of the $5 S$ system, the multifactor productivity of EPYLLION STYLES LTD. was $52.16 \%$, and after the implementation of $5 \mathrm{~S}$, the multifactor productivity assumed $59.98 \%$. The reason behind it was that implementation of $5 S$ during the study mainly focused on making tools and materials more easily accessible to workers, which enhanced labor productivity rather than trying to reduce the wastage and material cost.

This slight increase in material productivity came as by the implementation of $5 \mathrm{~S}$ as labor productivity became significantly high after the application of $5 S$ in the factory it had a positive impact on the multifactor productivity of the factory. The result shown in the following figure:

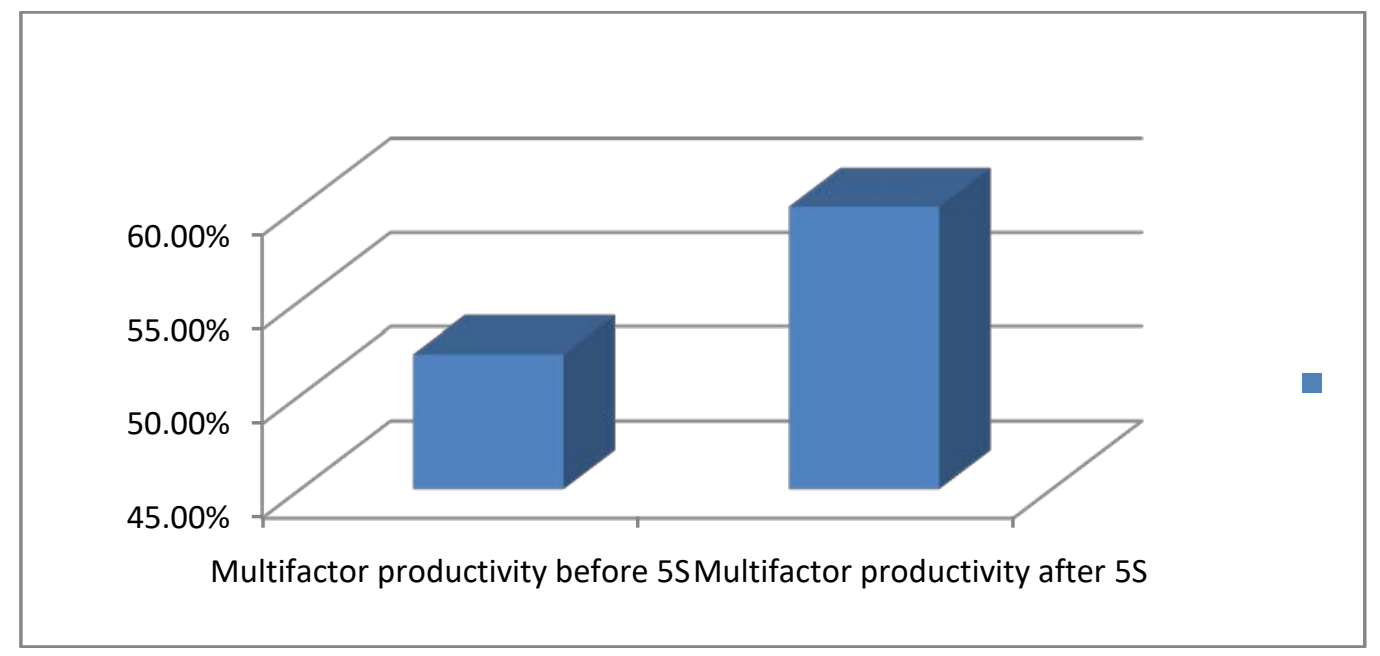

Figure 8: Comparison of multifactor productivity

\section{Conclusion}

The above activity performed on some of the renowned garments factories, and through $5 S$ Japanese principles, some great results come in very short period. It is required to continue the audit activity on a regular basis and allocated resources and budget to maintain the 5S. The 5S committee needs to propagate the philosophy to every employee by training and awareness program, and a continuous improvement activity is required to enhance the production and reduce the wastages. It can also be a part of the yearly 
appraisal. The Japanese 5S System is a very essential system for ensuring systematic discipline. Moreover, this is a world-wide acceptable formula which helps in a great deal in solving the managerial level problems. 5S can be considered a philosophy, a way of life, which can raise morale and create a good impression to customers and enhance efficiency. $5 S$ is a proven methodology and gives remarkable results all over the world. Bangladesh's industry needs to adopt it as an initial step toward modern management approaches.

\section{References Références Referencias}

1. Bullington, KE. (May 2005)"Lean Supply Strategies: Applying 5S Tools to Supply Chain Management," 90th Annual International Supply Management Conference

2. Rahman, M, N, A; Khamis, N, K; Zain, R, M;, Deros, $\mathrm{B}, \mathrm{M}$; and Mahmood, W,H,W; "Implementation of $5 \mathrm{~S}$ Practices in the Manufacturing Companies: A Case Study," American Journal of Applied Sciences 7 (8): 1182-1189, pp.1184-1186, 2010.IMPLEMENTATION OF 5S AND ITS EFFECT IN A S ELECTED GARMENTS FACTORY: A CASE S TUDY-Kazi Aminulhoque, Sudipta Choudhury, Abdullah Shakhawat.

3. Application of 5 S System in the Sample Section of an Apparel Industry for Smooth Sample DispatchAdnan Maroof Khan and Md. Mazedul Islam Department of Textile Engineering, Daffodil International University, Bangladesh www.isca.in

4. Abdulmalek F.A. and Rajgopal J., Analyzing the benefits of Lean Manufacturing and Value Stream Mapping via simulation: a process sector case study, International Journal of Production Economics, 107, 223-36 (2007)

5. Hines P., Rich N. and Esain A., Value stream mapping-a distribution industry application, Benchmarking International Journal, 6(1),60-77 (1999)www.mister-wong.com/users/258374111/ United States(2013)freedownloadbooks.net/5ssystem-pdf-ppt-ppt.html. (2013)Introduction to Lean (n.d.). Available from: http://www.mamtc.com/ lean/intro intro.asp (Accessed 10 May 2010) (2010)

6. Liker J.K. and Meier D., The Toyota Way, Field Book, Tata McGraw-Hill Edition, New Delhi, 41(2007).

7. Gapp, R., Fisher, R., Kobayashi, K. 2008. Implementing 5S within a Japanese Context: An Integrated Management System, Management Decision. 46(4): 565-579. Ortiz, Chris A. and Park, Murry. 2010. Visual Controls: Applying Visual Management to the Factory. New York: Productivity Press.

8. Hirano, Hiroyuki (1995). 5 Pillars of the Visual Workplace. Cambridge, MA: Productivity Press. Osada, Takashi (1995). The 5S's: Five keys to a
Total Quality Environment. US: Asian Productivity Organization.

9. R.T. Salunkhe, G.S. Kamble, Prasad Malage. "Inventory Control and Spare Part Management through 5S, KANBAN and Kaizen at ABC Industry ". "IOSR Journal of Mechanical and Civil Engineering (IOSR-JMCE) ISSN:2278-1684,PP:43-47"

10. Improvement of Plant Layout by using $5 S$ techniqueAn industrial case study Dinesh B. Shinde1, Prashant N. Shende2 1(Department Of Mechanical Engineering, DMIETR Wardha, India) 2(Department Of Mechanical Engineering, YCCE Nagpur, India)

11. Baker, Michael. (2008). what is the "standardization" of lean manufacturing $5 \mathrm{~s}$ Retrieved from http://www. whatisleanmanufacturing.com 5S--Standardize.html Bersbach, Peter. (2010, March 29). Sustain: the fifth of the 5s's. Retrieved from http://www.sixsigma trainingconsulting.com/six-sigma-tools/sustain-thefifth-of-the-5s\%E2\%80\%99sl. Beyond Lean (2010). "5S in the office," by Beyond Lean (BL).

12. A Practical Approach to the Successful Practice of 5S -Pradeep Mahalik. file:///C:/Users/EEEPC/ Desktop/project\%20n\%20cv/A\%20Practical\%20App roach\%20to\%20the\%20Successful\%20Practice\%20 of\%205S.html

13. 5S Conditions and Improvement Methodology in Apparel Industry in Pakistan Hammad Saeed Shamsi HIESS, Hamdard Univeristy, Pakistan

14. www.prgmea.org, www.iosrjournal.org

15. Implementing 5S Workplace Organization Methodology Programs In Manufacturing facilitiesLista International Corporation, http://www.epa. gov/lean/thinking/fives.htm

16. https://www.coursehero.com/file/p7707j/The-resultis-shown-in-the-following-figure-The-fuselage-isdrawn-with-the-fan/

17. http://iosrjournals.org/iosr-jpte/papers/Vol1\%E2\% $80 \% A 6$

18. http://iaeme.com/MasterAdmin/uploa\%E2\%80\%A6

19. https://www.slideshare.net/rpatils/5-s51672\%E2\%80\%A6

20. https://www.irjet.net/archives/V4/i3/IRJET-V\%E2\% $80 \% A 6$ 